\title{
Optimalisasi program usaha kesehatan sekolah untuk kesehatan mental siswa
}

\author{
Nurochim Nurochim \\ ${ }^{1}$ UIN Syarif Hidayatullah Jakarta
}

\begin{tabular}{l}
\hline Article Info \\
\hline Article history: \\
Received May 24th, 2020 \\
Revised Nov 12th, 2020 \\
Accepted Nov 27th, 2020
\end{tabular}

Keyword:

School health promotion

Mental health

Institution

Cognitive frame

Social network

\begin{abstract}
Health and education are important factors in the sustainability of a country. Health is not only physical health but also mental health is very important to maintain its quality. Student mental health is a condition without mental disorders, health because of stress, so it can play a role in life. The method used in this article is literature review. This study seeks to uncover how school health efforts are as effective programs to promote school-based mental health. Research results show that a planned and measured health business program can be a means of promoting school-based mental health. The school health promotion program is health education, health services, and fostering a healthy school environment. An effective and efficient school health promotion program is supported by strong leadership and cooperation across related sectors. This is supported by three forces namely, institutions, cognitive frames, and social networks.
\end{abstract}

(C) 2020 The Authors. Published by Indonesian Institute for Counseling, Education and Therapy (IICET). This is an open access article under the CC BY license (https://creativecommons.org/licenses/by/4.0/)

\section{Corresponding Author:}

Nurochim Nurochim,

UIN Syarif Hidayatullah Jakarta

Email: nurochim@uinjkt.ac.id

\section{Pendahuluan}

Pendidikan dan kesehatan merupakan hak dasar yang harus disediakan oleh Negara dalam konsep welfare state (Kiswanto, 2005). Hal tersebut juga tertulis dalam Undang-Undang Dasar 1945 Pasal 31 dan Pasal $28 \mathrm{H}$ serta pasal 34. Sekolah sebagai salah satu lembaga pendidikan mewujudkan sumber daya manusia dengan meningkatkan mutunya, melalui proses dan aktivitas pendidikan (Yanto \& Fathurrochman, 2019). Tujuan pendidikan yakni mewujudkan sumber daya manusia yang utuh baik dari segi sikap sosial, spiritual, dan pengetahuan serta keterampilan merupakan proses yang kompleks, proses yang kompleks untuk mencapai tujuan yang kompleks (Munifah et al., 2019). Pendidikan juga memiliki peran sosial, bersama dengan keluarga dalam mensosialisasikan bahwa para pemuda memiliki tanggung jawab dan kontribusi terhadap sebuah masyarakat. Layanan kesehatan preventif yang berfokus pada kesehatan anak dan kinerja pendidikan penting dikembangkan.

Integrasi layanan kesehatan preventif dalam sistem pendidikan membantu mendeteksi permasalahan kesehatan fisik dan mental siswa dan lebih lanjut berdampak pada peningkatan kesehatan dan mutu kognitifnya siswa. Proses pengorganisasian pendidikan tersebut bersifat komprehensif, termasuk pembiasaan kehidupan sehat, baik sehat secara mental dan fisik. Kesehatan mental siswa sangat penting untuk mencapai prestasi belajar yang optimal. Sekolah yang sehat saling terkait dengan mutu sekolah yang tergambar dalam profil kesehatan dan perilaku kesehatan siswa (Lee et al., 2018).

Populasi anak usia sekolah yang banyak sebagai sumber daya manusia, namun juga merupakan kelompok yang terancam kesehatan dan kesejahterannya antara lain adanya: penyalahgunaan narkoba dan rokok, kekerasan fisik dan mental, perkosaan dan eksploitasi seksual, konflik, ketimpangan gender, kebersihan dan keamanan lingkungan, kesehatan reproduksi, perilaku seks bebas, kehamilan dan aborsi yang tidak aman. Berdasarkan hasil penelitian, prevalensi merokok pada anak usia sekolah mengalami 
peningkatan (Riset Kesehatan Dasar, 2018:72). Hal tersebut sebagai indikasi bahwa aktivitas anak usia sekolah menengah kurang sehat, selain itu biaya hidup dikeluarkan untuk membeli rokok. Remaja yang belum memperoleh penghasilan, bisa berpotensi berperilaku menyimpang untuk mendapatkan rokok.Berbagai kondisi mengenai siswa seperti tawuran, perundungan, bunuh diri, rasa rendah diri, khawatir cemas, merupakan penggambaran mengenai kondisi kesehatan mental siswa. Kesehatan mental, pencegahan cidera, kecekalaan, dan kekerasan belum menjadi kegiatan layanan kesehatan berbasis sekolah secara rutin (Baltag, Pachyna, \& Hall, 2015).

Layanan kesehatan fisik dan mental berbasis sekolah dilaksanakan melaui program usaha kesehatan sekolah/madrasah (UKS/M). UKS sebagai upaya membina dan mengembangkan perilaku hidup sehat yang dilakukan secara terpadu melalui program pendidikan dan pelayanan kesehatan di sekolah, perguruan agama serta usaha-usaha yang dilaksanakan dalam rangka pembinaan dan pemeliharaan kesehatan di lingkungan sekolah. Melalui UKSlah budaya preventif ditumbuhkan, guna mengurangi pembiayaan kuratif. Lingkungan sekolah yang sehat, makanan yang dikonsumsi sehat maka akan berpengaruh terhadap proses pembelajaran.

Usaha kesehatan sekolah memiliki tujuan untuk membentuk kebiasaan hidup sehat dan meningkatkan derajat kesehatan peserta didik pada khususnya dan semua warga sekolah secara umum. Derajat kesehatan tersebut mencakup: (1) memiliki pengetahuan, sikap, dan keterampilan melaksanakan perilaku hidup sehat dan dapat berperan aktif melaksanakan upaya peningkatan kesehatan di lingkungan sekolah, keluarga, dan masyarakat; (2) sehat secara fisik, mental, sosial, dan lingkungan; (3) memiliki kecakapan hidup dan daya juang terhadap pengaruh buruk, penyalahgunaan narkoba dan obat terlarang, minuman keras, perilaku merokok, pornografi, dan masalah sosial lainnya (Kementerian Kesehatan Republik Indonesia, 2016b, pedoman akselerasi pembinaan, dan pelaksanaan UKS). Usaha kesehatan berbasis sekolah merupakan akses terhadap kesehatan prefentiv, identifikasi awal kesehatan, dan rujukan lanjut baik kesehatan mental dan fisik. Usaha kesehatan sebagai upaya perluasan akses kesehatan memerlukan peran pemimpin sekolah untuk memiliki persepsi akan kesehatan warga sekolah khususnya siswa, selain itu pemimpin sekolah yang berrelasi dengan petugas kesehatan dan dinas terkait (Bezem et al., 2017).

\section{Method}

Metode yang digunakan dalam artikel ini adalah kajian literatur. Kajian literature membutuhkan multimodal pengumpulan sumber data berupa data laporan maupun pembahan dan penelitian ilmiah dan presentasi kreatif (Mannay, 2013). Dengan kajian litertatur, pemahaman dapat dilaksanakan secara luas dan mendalam terhadap suatu rangkaian pengetahuan, kajian literatur dilaksanakan dengan meringkas, menganalisis, dan sintesis terhadap kelompok literatur (Xiao \& Watson, 2019). Kajian literatur melibatkan interpretasi penulis terhadap sebuah field (Montuori, 2005). Kesehatan mental siswa sangat penting dikaji dari berbagai sudut pandang keilmuan. Literatur yang dikaji dalam artikel ini adalah literatur yang membahas kesehatan mental, dan optimalisasi pelaksanaan program (UKS). Dengan kajian yang komprehensif tersebut diupayakan dapat mengembangkan peta keilmuan tentang upaya memelihara dan meningkatkan kesehatan mental siswa. Kesehatan mental berbasis sekolah dikaji berdasarkan sudut pandang organisasi, berupa bagaimana perilaku tentang program kesehatan siswa tentang peraturan, jejaring, dan kerangka pikir para pemangku kebijakan.

\section{Hasil dan Pembahasan}

\section{Indikator kesehatan mental dan kesehatan mental siswa}

Kondisi kesehatan mental siswa menjadi aspek penting sebab menentukan kualitas sumber daya manusia suatu bangsa. Siswa yang tumbuh dalam kondisi mental yang sehat merupakan sumber daya yang poetensial (Lubis, Sati, Adhinda, Yulianirta, \& Hidayat, 2019). Kesehatan mental siswa berupa perundungan menjadi isu kebijakan publik yang penting, dan menjadi perhatian para akademisi, sosial dan politik, dan menjadi permasalahan penting di banyak sekolah. Kesehatan mental siswa merupakan target yang kompleks dari berbagai individu dan situasi (Dresler-Hawke \& Whitehead, 2009). Selain itu kesehatan mental tanpa penggunaan alkohol juga menjadi permasalahan para remaja, kerangka kerja yang kompleks juga penting dalam hal ini, pendidikan mengenai dampak penyalahgunaan alkohol menjadi daya juang (Yassin, Afifi, Singh, Saad, \& Ghandour, 2018). Faktor kontekstual yang berkaitan dengan setting masyarakat yang melibatkan stakeholder dan karakter program tersebut (Darlington, Violon, \& Jourdan, 2018). Mental yang sehat merupakan kondisi emosional tanpa kecemasan, semangat, antusial, tidur nyenyak dan cukup, tidak menyakiti orang lain, tidak ingin bunuh diri. Para remaja tidak jarang mencoba hal baru untuk menunjukkan 
dirinya sebagai orang dewasa, sehingga melakukan hal-hal berresiko seperti mengkonsumsi alkohol, merokok, memiliki perilaku seksual, berbeda pendapat dengan orang lain (Mubasyiroh, Suryaputri, \& Tjandrarini, 2017).

Kesehatan mental siswa adalah kondisi bekerjanya fungsi0fungsi mental dalam diri siswa secara optimal sehingga siswa dapat melaksanakan aktivitas yang produktif pada ranahnya, seperti belajar dengan baik, mampu berelasi interpersonal yang baik dengan orang lain, baik antar siswa, dengan guru, orang tua, maupun orang yang terlibat dalam masa pendidikannya, siswa dapat menyesuaikan diri dengan perubahan hidupnya baik perubahan besar maupun kecil baik perubahan fisik, sosial, dan emosionalnya, selain itu siswa mampu mengelola berbagai kegagalan dalam hidupnya sehingga dapat berkegiatan dengan baik (Hanurawan, 2012). Lebih lanjut kesehatan mental siswa, adalah kesehatan mental di kelas adalah kondisi kelas dengan kondisi ekspresi yang dihargani, penerimaan yang baik, penghargaan diri, dan rasa terlindungi di kelas (Badaruddin, Erlamsyah, \& Said, 2016). Siswa yang memiliki kesehatan mental yang baik dapat berpartisipasi sosial dan ekonomi secara aktif, sehingga tidak dianggap sebagai pembuat onar oleh lingkungan (Suryanto, Herdiana, \& Chusairi, 2017).

Kesehatan mental siswa merupakan kondisi tanpa gangguan mental, tidak sakit karena stress, sesuai dengan kapasitasnya selaras dengan lingkungannya, seperti dapat menjaga ketetiban lingkungan, selain itu siswa dapat tumbuh dan berkembang secara positif. Gangguan mental dikaji dari gejala fisik maupun mental yaitu hysteria, seperti perasaan tertekan, gelisah, cemas, psikosomatis seperti tukak lambung, gangguan makan, amnesia, berkelana tanpa sadar, kepribadian ganda, kepribadian sosiopatik, dispersonalisasi, kelelahan, lesu walaupun fisik terlihat sehat, dan kelainan seksual (Purnama \& Prasetyo, 2016). Kondisi sakit fisik berkaitan dengan kesehatan mental, sebaliknya kondisi mental yang sakit dapat menimbulkan sakit fisik (Rosyad, 2016). Kesehatan mental siswa bukan hanya tidak adanya kondisi tekanan psikologis tetapi juga berkaitan dengan kondisi kesejahteraan psikologis yang berpengaruh terhadap kondisi kehidupannya seperti perasaan gembira, tertarik, dan dapat menikmati hidup yang dijalaninya (Faizah \& Amna, 2017).

\section{Usaha kesehatan sekolah}

Konsep WHO tentang uaha kesehatan sekolah program awalnya berfokus pada mengajarkan kepada siswa tentang kesehatan dan faktor yang mempengaruhi kesehatan, kemudian mengembangkan keterampilan siswa tentang penerapan gaya hidup yang sehat. Program awal tersebut bertujuan sebagai kerangka kerja strategi peningkatan mutu kesehatan Negara dengan pendekatan multisektor (World Health Organization Europe, 2006). Program usaha kesehatan sekolah dapat diselaraskan dengan program-program Negara yang lain, untuk meningkatkan mutu sumber daya manusia. Konsolidasi lintas sektor dapat saling melengkapi berbagai kekurangan program masing-masing sektor, seperti skema pendanaan (Parsons, 2004).

WHO meluncurkan Global School Health Initiative dengan tujuan untuk meningkatkan jumlah sekolah yang betul-betul disebut Health-Promoting School (HPS). HPS digambarkan dengan sekolah yang : (1) membangun kesehatan dan pembelajaran dengan melibatkan lingkungan pendidikan dan kesehatan, guru, organisasi guru, siswa, orang tua, penyedia layanan kesehatan, dan pemimpin masyarakat yang saling bekerjasama menjadikan sekolah tempat yang sehat; (2) berusaha keras untuk menyediakan lingkungan yang sehat, pendidikan kesehatan sekolah, dan layanan kesehatan sekolah bersamaan dengan pengembangan masyarakat, promosi kesehatan untuk staf sekolah, dan program gizi dan keamanan pangan, adanya program pendidikan jasmani dan rekreasi, program konseling, dukungan sosial, promosi kesehatan mental (Cheryl Vince Whitman \& Aldinger, 2011).

Usaha kesehatan sekolah sebagai program layanan kesehatan berbasis sekolah didalamnya termasuk upaya preventif, deteksi awal, dan intervensi kesehatan fisik, sosial, dan mental anak (Baltag et al., 2015). Usaha kesehatan sekolah Area layanan kesehatan adalah kesehatan mental, kesehatan seksual dan reproduksi, kesehatan gigi, penyakit menular, pendengaran, penglihatan, nutrisi, penyakit kronis, ortopedi, bahaya penggunaan narkoba, dampak kekerasan, perawatan darurat, endokrinologi, dan neurologi. Jenis layanan yang dilaksanakan adalah penjaringan, pendidikan atau promosi, konseling, rujukan kesehatan, vaksinasi, penyediaan atau perawatan. Berbagai permasalahan dan tantangan berbasis organisasi seperti sumber daya manusia, keuangan, koordinasi, dukungan masyarakat, kebijakan, dan kesetaraan.

Tujuan dari program usaha kesehatan sekolah selain meningkatkan kesehatan lingkungan sekolah, juga meningkatkan budaya perilaku hidup sehat yang berkontribusi terhadap status kesehatan fisik dan psikologis siswa, guru, dan mempromosikannya kepada lingkungan dimana mereka tinggal. Perilaku hidup sehat dapat diseminasikan dari sekolah hingga keluarga dan masyarakat (Yee Ki Fong \& Lik Hak Wong, 2002). 
Kedisiplinan diri siswa dan warga sekolah dikembangkan untuk tidak memiliki permasalahan mengenai minum beralkohol, merokok, kekerasan, perundungan, dan kebiasaan makan yang bergizi.

Sekolah yang menerapkan usaha kesehatan sekolah juga berupaya dan berkomitmen secara menyeluruh antar warga sekolah, atas manfaat program bagi siswa, staff, orang tua, dan masyarakat luas. Sekolah berkontribusi besar terhadap kesehatan dan kesejahteraan (well-being) siswa (Gillies, Dimitrijevich, \& Lambert, 1997). Kesenjangan layanan kesehatan dapat diantisipasi dengan adanya mengelola konteks sosial yang melingkupi pelaksanaan program.

Usaha kesehatan sekolah berorientasi pada konteks sekolah, konsisten dengan kebijakan sekolah dengan melibatkan staff sekolah, siswa, guru, dan berbagai peran lainnya dalam hal desain kesegiatan hingga evaluasi. Kegiatan usaha kesehatan sekolah harus mendukung pengembangan keterampilan guru, siswa, dan warga sekolah dan mendorong partisipasi seluruh warga sekolah. Usaha kesehatan sekolah merupakan aktivitas untuk meningkatkan dan melindungi kesehatan warga sekolah dalam komunitas sekolah. Kegiatan tersebut menyiratkan sekolah sehat, lingkungan sekolah sebagai tempat fisik dan sosial, kurikulum pendidikan untuk kesehatan, kegiatan yang bekerjasama dengan pihak lain yang ditujukan untuk layanan kesehatan (Iudici, 2015).

Usaha kesehatan sekolah memiliki tujuan untuk membentuk kebiasaan hidup sehat dan meningkatkan derajat kesehatan peserta didik pada khususnya dan semua warga sekolah secara umum. Derajat kesehatan tersebut mencakup: (1) memiliki pengetahuan, sikap, dan keterampilan melaksanakan perilaku hidup sehat dan dapat berperan aktif melaksanakan upaya peningkatan kesehatan di lingkungan sekolah, keluarga, dan masyarakat; (2) sehat secara fisik, mental, sosial, dan lingkungan; (3) memiliki kecakapan hidup dan daya juang terhadap pengaruh buruk, penyalahgunaan narkoba dan obat terlarang, minuman keras, perilaku merokok, pornografi, dan masalah sosial lainnya (Kementerian Kesehatan Republik Indonesia, 2016b, pedoman akselerasi pembinaan, dan pelaksanaan UKS). Usaha kesehatan berbasis sekolah merupakan akses terhadap kesehatan prefentiv, identifikasi awal kesehatan, dan rujukan lanjut baik kesehatan mental dan fisik. Usaha kesehatan sebagai upaya perluasan akses kesehatan memerlukan peran pemimpin sekolah untuk memiliki persepsi akan kesehatan warga sekolah khususnya siswa, selain itu pemimpin sekolah yang berrelasi dengan petugas kesehatan dan dinas terkait (Bezem et al., 2017).

Dalam konteks Indonesia, Sejak tahun 1984 dengan dikeluarkannya SKB 4 Menteri (Departemen Kesehatan, Departemen Agama, Departemen Pendidikan Nasional dan Departemen Dalam Negeri) program UKS mulai diterapkan secara terintegrasi dengan lintas sektor terkait, yang selanjutnya pada tahun 1991 dilakukan Lomba Sekolah Sehat (LSS) tingkat Nasional. Pada tahun 2003, SKB 4 Menteri tersebut direvisi sesuai dengan situasi desentralisasi dan perkembangan program UKS, dimana sasaran UKS meluas mulai dari tingkat TK/RA, SD/MI, SMP/MTs, SMA/SMK/MA. Pada tahun 2014, SKB 4 Menteri tersebut direvisi kembali menjadi Peraturan Bersama 4 Menteri dimana terdapat penambahan kata Madrasah, menjadi Usaha Kesehatan Sekolah/Madrasah (UKS/M). Peraturan bersama tersebut menunjukkan bahwa keberlangsungan dan keterlaksanaan UKS tidak hanya menjadi kewajiban pihak sekolah, namun juga lintas sektor terkait seperti dinas kesehatan, kementerian agama, dan pemerintah lokal terdekat.

Keberlangsungan program usaha kesehatan sekolah bergantung pada kerjasama di berbagai level kewenangan program, baik di tingkat sekolah, lokal, dan nasional. Di tingkat sekolah masing-masing aktor baik kepala sekolah, guru, siswa beperan dalam meningkatkan literasi program. Di tingkat makro kebijakan memiliki peran meningkatkan literasi dan menetapka kebijakan yang mendukung program, seperti menetapkan petunjuk kurikulum yang integratif dengan kesehatan, petunjuk bagi pembagian peran pendanaan lintas sektor, tentunya literasi akan pendidikan tidak hanya dilihat sebagai fitur akademik.

\section{Usaha kesehatan sekolah dan kesehatan mental siswa}

Berbagai cara ilmiah dibutuhkan bagi kegiatan preventif di sekolah termasuk pemetaan sumber daya manusia, evaluasi yang valid dan reliabel, penyaringan kesehatan mental komprehensif, pengembangan model logic, memilih sebuah teori untuk perubahan, monitoring, dan dampak yang diharapkan dari program kesehatan mental. Dalam pembahasan dalam lingkup yang lebih luas, model sosio ekologis dirancang untuk mengembangkan pengetahuan kerja yang kuat tentang ilmu pencegahan dan kesehatan masyarakat. Model sosio ekologis yang dikembangkan dapat mempengaruhi pengembangan layanan komprehensif untuk semua siswa, di semua tingkatan satuan pendidikan (Macklem, 2014).

Usaha kesehatan sekolah adalah program untuk promosi kesehatan, tidak hanya kesehatan fisik namun juga kesehatan jiwa. Upaya kesehatan jiwa untuk yang melibatkan orang tua agar ikut serta dalam membiasakan makan yang bergizi pada anak, membiasakan hidup sehat dan bersih di rumah, menyesuaikan 
diri dengan program kesehatan dan berupaya secara aktif untuk mengetahui kegiatan putra dan putrinya di sekolah (Limbu, Mochny, \& Sulistyowati, 2012). Hal tersebut menunjukkan bahwa kegiatan UKS berupaya untuk membentuk jejaring aktif antara orang tua dan sekolah, sehingga upaya membentuk kesehatan mental siswa dapat terencana dan terukur secara komprehensif.

Program usaha kesehatan sekolah sebagai salah satu akses kesehatan preventif siswa menjadi kegiatan yang penting dikembangkan dalam lingkup pengelolaan pendidikan yang professional. Namun demikian berbagai masalah muncul dalam upaya optimalisasinya yakni anggaran dan tenaga ahli yang kurang. Oleh sebab itu para professional sekolah sangat penting meningkatkan kesadaran tentang akses kesehatan preventif, sehingga dapat merancang program dengan berbagai kerjasama berbasis kebijakan (Bezem et al., 2017).

Penting adanya kolaborasi antara sekolah, lembaga kesehatan masyarakat, dan orang tua dalam mewujudkan kesehatan fisik dan mental siswa. Kolaborasi upaya kesehatan sekolah yang berbasis riset empirik dan teoretik merupakan syarat penting demi terwujudnya mental siswa yang sehat. Riset-riset yang dilaksanakan merupakan kerjasama antara universitas dan lembaga penelitian, dapat menjadi basis rancangan program pelaksanaan usaha kesehatan sekolah.

Dalam kerangka organisasi, sebuah sistem kesehatan melibatkan setiap orang untuk terlibat secara bersama-sama. Pengelola sekolah yang sering bekerjasama dengan petugas kesehatan maka akan membentuk kerjasama dan relasi positif antara lingkup pendidikan dan kesehatan yang dapat mendukung terlaksananya usaha kesehatan yang efektif dan efisien. Persepsi pemimpin lembaga pendidikan akan pentingnya sebuah program kesehatan berbasis sekolah menjadi dukungan iklim positif pelaksanaan program UKS. Variable budaya dan norma masing-masing organsiasi juga menentukan faktor efektivitas program, ditambah dengan kepemimpinan yang kuat.

Dinamika pelaksanaan suatu kebijakan atau program dapat disesuaikan dan dikembangkan dengan mengubah kebijakan, penguatan sumber daya dan relasi kelembagaan, dan mendukung pengembangan kepemimpinan (Trickett \& Beehler, 2013). Untuk mendukung terlaksanannya program kesehatan mental berbasis sekolah sangat penting untuk menciptkaan dan melanggengkan perilaku masyarakat sekolah yang sadar dan mendukung kesehatan mental. Penciptaan perilaku tersebut harus diciptakan dengan tiga kekuatan besar, yakni institusi, social network, dan cognitive frame (Beckert, 2010). Institusi berupa normanorma dan aturan yang mengatur perilaku manusia atau kelompok dalam aspek kesehatan mental berbasis sekolah. Aspek kelembagaan ini masih membutuhkan sosialisasi seperti surat keputusan bersama pengelolaan UKS/M dan petunjuk teknis pelaksanaan UKS, dan buku-buku yang harus diisi mengenai kesehatan siswa. Selain itu institusi berupa koordinasi masing-masing sektor terkait masih lemah (Limbu et al., 2012). Sekolah juga masih ada yang belum melaksanaan kegiatan UKS/M secara optimal. Cognitive frame adalah sikap dan cara berpikir tentang kesehatan mental berbasis sekolah, masih harus dihabituskan. Social network, aspek ini meliputi relasi sosial antar warga sekolah, antar sekolah, dinas pendidikan, dinas kesehatan, pemerintah daerah, dan kementerian agama. Dalam konteks Indonesia social network ini berbentuk kegotongroyongan untuk membentuk sikap yang mementingkan kesehatan mental siswa (Ricardi S. Adnan, 2019).

Pelaksanaan UKS dapat mendukung kualitas kesehatan mental siswa, sebab dapat meningkatkan kerjasama dan relasi antara siswa, orang tua, dan guru, meningkatkan kualitas sosial, mengurangi kecelakaan dan luka di tempat belajar, mengurangi perilaku merokok, dan preventif terhadap perilaku penyalahgunaan minuman keras dan obat terlarang (Aldinger et al., 2008).

\section{Kesimpulan}

Kesehatan mental siswa dapat diwujudkan dan ditingkatkan melaui pelaksanaan program UKS yang berdasarkan pada data-data nyata dan kondisi yang ada pada masing-masing sekolah. Dengan pelaksaan program UKS yang terencana dan dievaluasi dengan tepat maka kesehatan fisik dan mental warga sekolah, khususnya siswa dapat terwujud. UKS dirancang berbasis data, kepemimpinan sekolah yang mendukung keterlaksanaan UKS dengan efektif dan efisien dapat meningkatkan akses kesehatan preventif siswa dan meningkatkan mutu kesejahteraan siswa. Kepemimpinan pendidikan yang dapat bekerjasama dengan pihak terkait seperti dinas kesehatan, dinas pendidikan, kementerian agama, dan pihak pemerintah terdekat seperti kecamatan, keluarahan, dan kabupaten atau walikota. Pelaksanaan program UKS yang optimal memuat pendidikan kesehatan dan perubahan serta pembiasaan perilaku hidup bersih dan sehat, baik sehat secara 
fisik dan psikologis. Hal tersebut penting didukung dengan tiga kekuatan yakni institusi, kerangka kognitif, dan jejaring sosial, sehingga dapat membentuk habitus mental sehat berbass sekolah.

\section{Referensi}

Aldinger, C., Zhang, X. W., Liu, L. Q., Guo, J. X., Yu Sen Hai, \& Jones, J. (2008). Strategies for implementing Health-Promoting Schools in a province in China. Promotion \& Education, 15(1), 24-29. https://doi.org/10.1177/1025382307088095

Badaruddin, A., Erlamsyah, E., \& Said, A. (2016). Hubungan Kesehatan Mental dengan Motivasi Belajar Siswa. Konselor, 5(1), 50. https://doi.org/10.24036/02016516543-0-00

Baltag, V., Pachyna, A., \& Hall, J. (2015). Global Overview of School Health Services: Data from 102 Countries. Health Behavior and Policy Review, 2(4), 268-283. https://doi.org/10.14485/hbpr.2.4.4

Beckert, J. (2010). How do Fields Change? The Interrelations of Institutions, Networks, and Cognition in the Dynamics of Markets. Organization Studies, 31(5), 605-627. https://doi.org/10.1177/0170840610372184

Bezem, J., Heinen, D., Reis, R., Buitendijk, S. E., Numans, M. E., \& Kocken, P. L. (2017). Improving access to school health services as perceived by school professionals. BMC Health Services Research, 17(743), 1-8. https://doi.org/10.1186/s12913-017-2711-4

Cheryl Vince Whitman, \& Aldinger, C. E. (2011). Case Studies in Global School Health Promotion From Research to Practice. https://doi.org/10.1017/CBO9781107415324.004

Darlington, E. J., Violon, N., \& Jourdan, D. (2018). Implementation of health promotion programmes in schools: An approach to understand the influence of contextual factors on the process? BMC Public Health, 18(1), 1-17. https://doi.org/10.1186/s12889-017-5011-3

Dresler-Hawke, E., \& Whitehead, D. (2009). The behavioral ecological model as a framework for schoolbased anti-bullying health promotion interventions. Journal of School Nursing, 25(3), 195-204. https://doi.org/10.1177/1059840509334364

Faizah, F., \& Amna, Z. (2017). Bullying dan Kesehatan Mental Pada Remaja SMA di Banda Aceh. Maret, $3(1), 77$.

Gillies, S., Dimitrijevich, S., \& Lambert, M. (1997). What is a health promoting school? The Indian Journal of Pediatrics, 64(1), 104-104. https://doi.org/10.1007/bf02795787

Hanurawan, F. (2012). Strategi Pengembangan Kesehatan Mental Di Lingkungan Sekolah. PSIKOPEDAGOGIA Jurnal Bimbingan Dan Konseling, https://doi.org/10.12928/psikopedagogia.v1i1.2572

Iudici, A. (2015). Health Promotion in School: Theory, Practice, and Clinical Implications. New York: Nova Publishers New York.

Kementerian Kesehatan Republik Indonesia. (2016). Pedoman Akselerasi Pembinaan dan Pelaksanaan UKS. In Bina Kesehatan Anak, Depkes RI. https://doi.org/10.3406/arch.1977.1322

Kiswanto, E. (2005). Negara Kesejahteraan (Welfare State): Mengembalikan Peran Negara Dalam Pembangunan Kesejahteraan Sosial di Indonesia. JKAP (Jurnal Kebijakan Dan Administrasi Publik), Vol. 9, pp. 91-108. https://doi.org/10.22146/jkap.8320

Lee, A., St Leger, L. H., Ling, K. W. K., Keung, V. M. W., Lo, A. S. C., Kwong, A. C. M., ... Armstrong, E. S. (2018). The Hong Kong Healthy Schools Award Scheme, school health and student health: An exploratory study. Health Education Journal, 77(8), 857-871. https://doi.org/10.1177/0017896918779622

Limbu, R., Mochny, I. S., \& Sulistyowati, M. (2012). Analisis Pelaksanaan Tiga Program Pokok Usaha Kesehatan Sekolah (TRIAS UKS) Tingkat Sekolah Dasar Kecamatan Blimbing Kota Malang. The Indonesian Journal of Public Health, 9(1), 51-66. https://doi.org/10.1002/ejoc.201200111

Lubis, L. T., Sati, L., Adhinda, N. N., Yulianirta, H., \& Hidayat, B. (2019). Peningkatan Kesehatan Mental Anak dan Remaja Melalui Ibadah Keislaman. Al-Hikmah: Jurnal Agama Dan Ilmu Pengetahuan, 16(2), 120. https://doi.org/10.25299/jaip.2019.vol16(2).3898

Macklem, G. L. (2014). Preventive Mental Health at School: Evidence-Based Services for Students. In Preventive Mental Health at School. https://doi.org/10.1007/978-1-4614-8609-1

Mannay, D. (2013). Review article. Qualitative Research, 13(2), 242-244. https://doi.org/10.1177/1468794112450831

Montuori, A. (2005). Literature Review As Creative Inquiry: Reframing Scholarship As a Creative Process. Journal of Transformative Education, 3(4), 374-393. https://doi.org/10.1177/1541344605279381

Mubasyiroh, R., Suryaputri, I. Y., \& Tjandrarini, D. H. (2017). Determinan Gejala Mental Emosional 
Pelajar SMP-SMA di Indonesia Tahun 2015. Buletin Penelitian Kesehatan, 45(2), 103-112. https://doi.org/10.22435/bpk.v45i2.5820.103-112

Munifah, M., Tsani, I., Yasin, M., Tortop, H. S., Palupi, E. K., \& Umam, R. (2019). Management System of Education: Conceptual Similarity (Integration) between Japanese Learning System and Islamic Learning System in Indonesia. Tadris: Jurnal Keguruan Dan Ilmu Tarbiyah, 4(2), 159-170. https://doi.org/10.24042/tadris.v4i2.4893

Parsons, C. (2004). The Health Promoting School and Social Justice in a Global Environment. Asia Pacific Journal of Public Health, 16(1_suppl), 42-47. https://doi.org/10.1177/101053950401600S11

Purnama, D. S., \& Prasetyo. (2016). Modul Guru Pembelajar: Aplikasi Kesehatan Mental.

Ricardi S. Adnan. (2019). Bencana, Kelembagaan, dan Masyarakat. Talenta Conference Series: Local Wisdom, Social, and Arts (LWSA), 2(1), 1-11. https://doi.org/10.32734/1wsa.v2i1.621

Riset Kesehatan Dasar. (2018). Riset Kesehatan Dasar 2018. In Badan Penelitian dan Pengembangan Kesehatan Kementrian Kesehatan Republik Indonesia. https://doi.org/1 Desember 2013

Rosyad, R. (2016). Pengaruh Agama terhadap Kesehatan Mental. Syifa Al-Qutub, 1(1), 17-26.

Suryanto, S., Herdiana, I., \& Chusairi, A. (2017). Deteksi Dini Masalah Psikologis Pada Anak Jalanan Oleh Orangtua Asuh di Rumah Singgah. INSAN Jurnal Psikologi Dan Kesehatan Mental, 1(2), 85. https://doi.org/10.20473/jpkm.v1i22016.85-96

Trickett, E. J., \& Beehler, S. (2013). The Ecology of Multilevel Interventions to Reduce Social Inequalities in Health. American Behavioral Scientist, 57(8), 1227-1246. https://doi.org/10.1177/0002764213487342

World Health Organization Europe. (2006). What is the evidence on school health promotion in improving health or preventing disease and, specifically, what is the effectiveness of the health promoting schools approach? Denmark.

Xiao, Y., \& Watson, M. (2019). Guidance on Conducting a Systematic Literature Review. Journal of Planning Education and Research, 39(1), 93-112. https://doi.org/10.1177/0739456X17723971

Yanto, M., \& Fathurrochman, I. (2019). Manajemen kebijakan kepala madrasah dalam meningkatkan mutu pendidikan. Jurnal Konseling Dan Pendidikan, 7(3), 123-130. https://doi.org/10.29210/138700

Yassin, N., Afifi, R., Singh, N., Saad, R., \& Ghandour, L. (2018). "There Is Zero Regulation on the Selling of Alcohol": The Voice of the Youth on the Context and Determinants of Alcohol Drinking in Lebanon. Qualitative Health Research, 28(5), 733-744. https://doi.org/10.1177/1049732317750563

Yee Ki Fong, \& Lik Hak Wong. (2002). Family health: the perspective of bereaved children. Promotion \& Education, 9(1_suppl), 53-53. https://doi.org/10.1177/10253823020090010135 